УДК 664.64.016.8

DOI: 10.36461/NP.2019.52.3.010

\title{
ВЛИЯНИЕ РАННЕВЕСЕННЕЙ ПОДКОРМКИ СЕРОСОДЕРЖАЩИМИ МИНЕРАЛЬНЫМИ УДОБРЕНИЯМИ НА КАЧЕСТВО МУКИ ИЗ ЗЕРНА ОЗИМОЙ ПШЕНИЦЫ
}

Ф. А. Мударисов ${ }^{1}$, канд. с.-х. наук, доцент; М. К. Садыгова ${ }^{2}$, доктор техн. наук, профрессор; Э. Ш. Миначева ${ }^{2}$, магистр; А. А. Галиуллин ${ }^{3}$, канд. с.-х. наук, доцент

${ }^{1}$ Федеральное государственное бюджетное образовательное учреждение высшего образования «Ульяновский государственный аграрный университет им. им. П. А. Столыпина», Россия, т. 8(8422) 55-95-47, e-mail: fail_76@mail.ru;

${ }^{2}$ Федеральное государственное бюджетное образовательное учреждение высшего образования «Саратовский государственный аграрный университет им. Н. И. Вавилова», Россия, т. 8 (8452) 23-32-92, e-mail: sadigova.madina@yandex.ru;

${ }^{3}$ Федеральное государственное бюджетное образовательное учреждение высшего образования «Пензенский государственный аграрный университет», Россия, т. 8(8412) 628-151

В работе исследована пшеничная мука, полученная из зерна озимой мягкой пшеницы сорта Саратовская 17, выращенная в условиях чернозема выщелоченного, среднемощного, малогумусного, среднесуглинистого Среднего Поволжья Российской Федерации (Ульяновская область), в 2017-2018 гг. По мнению ведущих специалистов в области питания растений, наличие в культурных растениях достаточного количества серы - это основной фактор получения качественного белкового соединения. Изучалось влияние ранневесенней подкормки аммиачной селитрой с добавлением сульфата аммония в количестве 5 и $10 \%$. Содержание сырой клейковины в муке из зерна 2018 г. ниже на 4,5-7,0 \% по сравнению с вариантами опыта 2017 г., поэтому водопоглатительная способность (ВПС) в вариантах опыта 2018 г. ниже на две-три единицы. Использование серосодержащих удобрений при ранневесенней подкормке озимой пшеницы влияет на качество готовых изделий. При внесении серосодержащего удобрения в количестве $10 \%$ получили высокие показатели пористости, удельного объема хлеба и формоусточивости, что указывает на зависимость этих показателей от индексов глютена, вязкости и амилазы.

Ключевые слова: миксолаб, профиль теста, индекс профайлера, индекс глютена, серосодержащие удобрения.

\section{Введение}

В научной литературе имеются многочисленные данные об эфрфективности применения серы при выращивании сельскохозяйственных культур. Серосодержащие удобрения играют роль в оптимизации минерального питания серых лесных, дерново-подзолистых почв, типичного и обыкновенного черноземов $[8,11-13,16]$.

По мнению ведущих специалистов в области питания растений, наличие в культурных растениях достаточного количества серы - это основной фрактор получения качественного белкового соединения. От уровня поглощения серы зависит структура, а также функционирование ферментов и белков в вегетативных частях и урожае культур. Сера обеспечивает связь между ферментами, а также принимает участие в образовании третичной структуры белка. Из-за присутствия серы сохраняется трехмерная структура белка, а, следовательно, его активность. Например, у зерновых культур форма белковых молекул и функ- циональные свойства белка зависят от количества образующейся аминокислоты цистеина, в состав которой входит макроэлемент - сера. На основе данных исследований, хлеб, произведенный из зерна пшеницы с низким содержанием серы, не увеличивается в объеме, и объект получается плотным, не соответствующим требованиям стандарта по форме [4, 5, 17-19].

Специалисты компании «SocTrade» предлагают более прогрессивный, с точки зрения экономии времени и ресурсов, экспресс-метод оценки качества пшеничной муки. Использование прибора миксолаб позволит со временем отказаться от пробных лабораторных выпечек хлеба на этапе входного контроля сырья. В процессе анализа с помощью прибора миксолаб можно получить наиболее полный реологический профиль теста, детально характеризующий свойства конкретной партии муки и качество готового изделия [15].

Ученые из НИИСХ Юго-Востока также считают, что при проведении большого ко- 
личества различных исследований по изучению качества зерна пшеницы в процессе селекции для получения хлеба, проведение объемного анализа путем сокращения количества операций играет важную роль. Исходя из вышесказанного, представляют большой научный интерес новые параметры фризических свойств теста, оцениваемые на приборе миксолаб. Полученные экспериментальные данные свидетельствуют о достаточной информативности изученных признаков для дальнейшего широкого использования в селекции озимой пшеницы на качество зерна [1-3, 6-7, 9].

Цель исследования: обосновать влияние серосодержащих удобрений при ранневесенней подкормке озимой пшеницы на технологические свойства муки на основании реологического профиля теста.

\section{Методы и материалы}

Объект исследования - мука из зерна озимой мягкой пшеницы сорта Саратовская 17, выращенного на опытном поле Ульяновского ГАУ им. П. А. Столыпина в 20162018 гг. Почва опытного участка - чернозем выщелоченный, среднемощный, малогумусный среднесуглинистый. Содержание гумуса 4,3 \%. Обеспеченность подвижным фосфором повышенная, обменным калием высокая. Содержание $\mathrm{P}_{2} \mathrm{O}_{5}-115, \mathrm{~K}_{2} \mathrm{O}-139$ мг/кг почвы. Реакция среды рН - 6,1. Степень насыщенности основаниями 26,5 мгэкв / 100 г почвы. Содержание серы очень низкое, в пределах 0,3-1,3 мг/кг почвы.

Варианты опыта: 1) $\mathrm{NH}_{4} \mathrm{NO}_{3}$ (производственный контроль) - ранневесенняя подкормка аммиачной селитрой; 2) $\mathrm{NH}_{4} \mathrm{NO}_{3}+\mathrm{S}$ (5\%) - ранневесенняя подкормка аммиачной селитрой и сульфатом аммония; 3) $\mathrm{NH}_{4} \mathrm{NO}_{3}+\mathrm{S}(10 \%)$ - ранневесенняя подкормка аммиачной селитрой и сульфатом аммония.

Для проведения ранневесенней подкормки использовали серосодержащую аммиачную селитру из расчёта N 100, S 5 или S 10 кг/га в действующем веществе. Агротехника общепринятая. По климатическим показателям периоды вегетации опытной культуры по годам исследований различались. Период 2016-2017 гг. отличался большим количеством осадков, что в итоге привело к снижению устойчивости стеблей, полеганию растений, переносу даты уборки пшеницы, также возросли непредвиденные потери созревшего зерна опытной культуры при обмолоте, часть урожая не соответствовала требуемым базисным нормам по влажности и другим обязательным показателям заготовительных кондиций на пшеницу продовольственную. В 2017-2018 гг. количество осадков было ниже, по сравнению с предыдущим годом, а также отмечались более низкие зимние температуры (на 2-5 ${ }^{\circ} \mathrm{C}$ ниже 2017 года). Весенняя вегетация озимой пшеницы началась на 7-10 дней позже обычного. На почве местами наблюдались частые заморозки. Дата наступления фенофаз задержалась на две недели. Резкое увеличение дневной температуры воздуха до 28-33 ${ }^{\circ} \mathrm{C}$ при низком количестве осадков в июле и августе ускорили период налива зерна.

Водопоглощение и реологические свойства теста определяли по ГОСТ Р 544982011 с помощью миксолаба фрирмы «Шопен» (Франция) на базе ФГБНУ НИИСХ Юго-Востока (г. Саратов) в лаборатории качества зерна. Клейковину муки и ее качество определяли по ГОСТ 27839-2013, пробную выпечку проводили по ГОСТ 27669-88 в лаборатории хлебопекарного и кондитерского производства Ульяновского ГАУ. Массовая доля аминокислот определялась методом капиллярного электрофореза на системе «Капель 105М» в соответствии с адаптированной методикой М-0438-2009 (ФР.1.31.2010.07015) [10, 14].

\section{Результаты исследований}

Протокол Chopin+ анализирует пять фаз реологического анализа с различной температурой (от 30 до $90{ }^{\circ} \mathrm{C}$ ) и характеризует различные процессы: С1 - образование теста; C2 - разжижение теста; C3 максимальную скорость гелеобразования крахмала; C4, C5 - начало и окончание ретроградации крахмала в рамках эксперимента (рис. 1, 2) [3, 4, 5].

На основании результатов измерения значения крутящего момента в точках C1, C2, C3, C4, C5 и уровня ВПС (водопоглотительная способность) муки программа формирует реологический профиль теста (профайлер), который представляет собой радиальную диаграмму, по лучам которой в пропорции от 0 до 9 отложены следующие значения: ВПС, замешивание - C1, глютен + - С2, вязкость - С3, амилаза C4, загустевание - C5.

Таблица 1

Содержание и качество клейковины по вариантам опыта

\begin{tabular}{|l|c|c|c|c|}
\hline \multirow{2}{*}{ Вариант опыта } & \multicolumn{2}{|c|}{ Массовая доля клейковины, \% } & \multicolumn{2}{c|}{ Качество клейковины, ед. ИДК } \\
\cline { 2 - 5 } & 2017 г. & 2018 г. & 2017 г. & 2018 г. \\
\hline $\mathrm{NH}_{4} \mathrm{NO}_{3}$ (контроль) & $28,8 \pm 0,7$ & $26,8 \pm 0,5$ & $75 \pm 1,0$ & $55 \pm 1,5$ \\
\hline $\mathrm{NH}_{4} \mathrm{NO}_{3}+\mathrm{S} 5 \%$ & $27,0 \pm 0,5$ & $25,4 \pm 0,6$ & $80 \pm 1,0$ & $46 \pm 1,0$ \\
\hline $\mathrm{NH}_{4} \mathrm{NO}_{3}+\mathrm{S} 10 \%$ & $29,3 \pm 0,5$ & $28,0 \pm 0,5$ & $65 \pm 1,3$ & $60 \pm 1,0$ \\
\hline
\end{tabular}




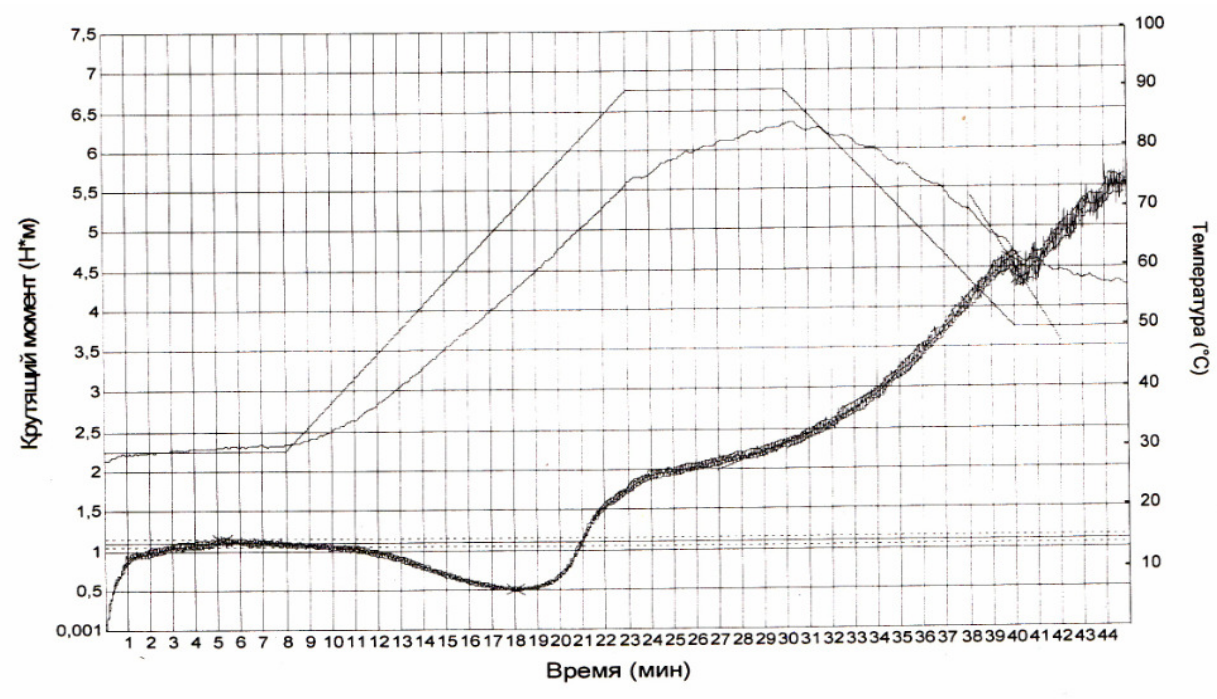

$1-\mathrm{NH}_{4} \mathrm{NO}_{3}$ (контроль) 2017 г.
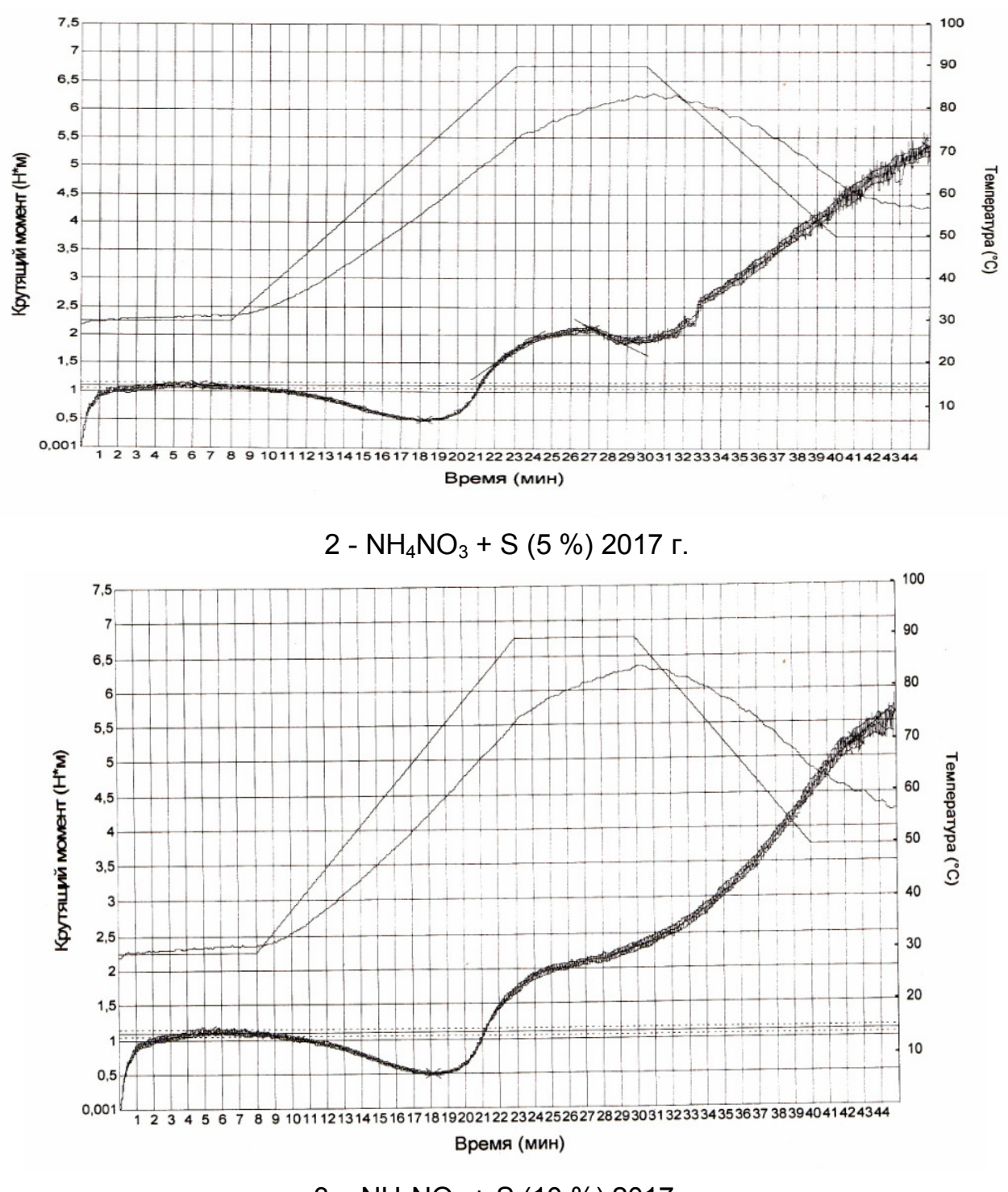

$3-\mathrm{NH}_{4} \mathrm{NO}_{3}+\mathrm{S}(10 \%) 2017$ г.

Puc. 1. Фазы реологического анализа на приборе миксолаб - 2017 год 

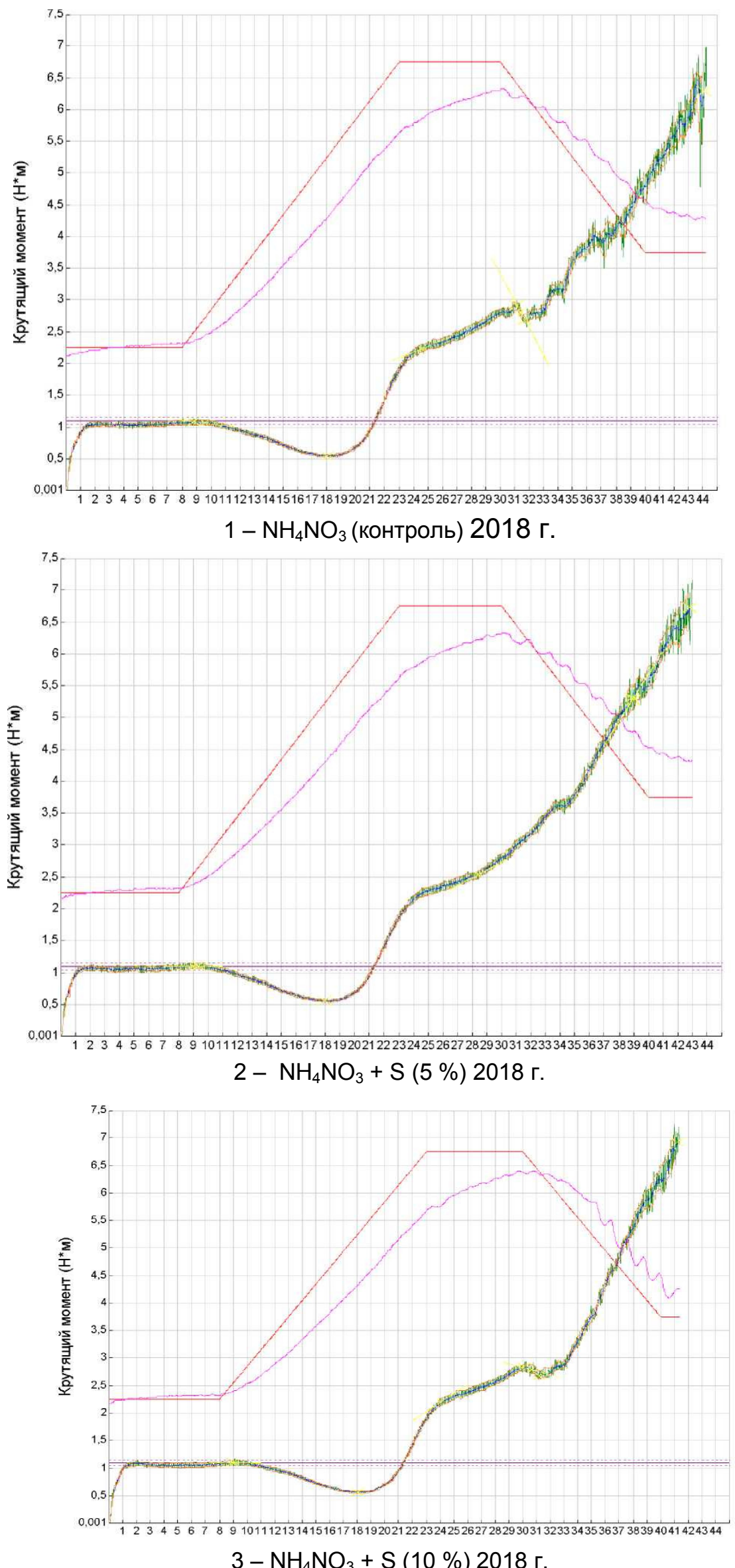

Puc. 2. Фазы реологического анализа на приборе миксолаб - 2018 год 

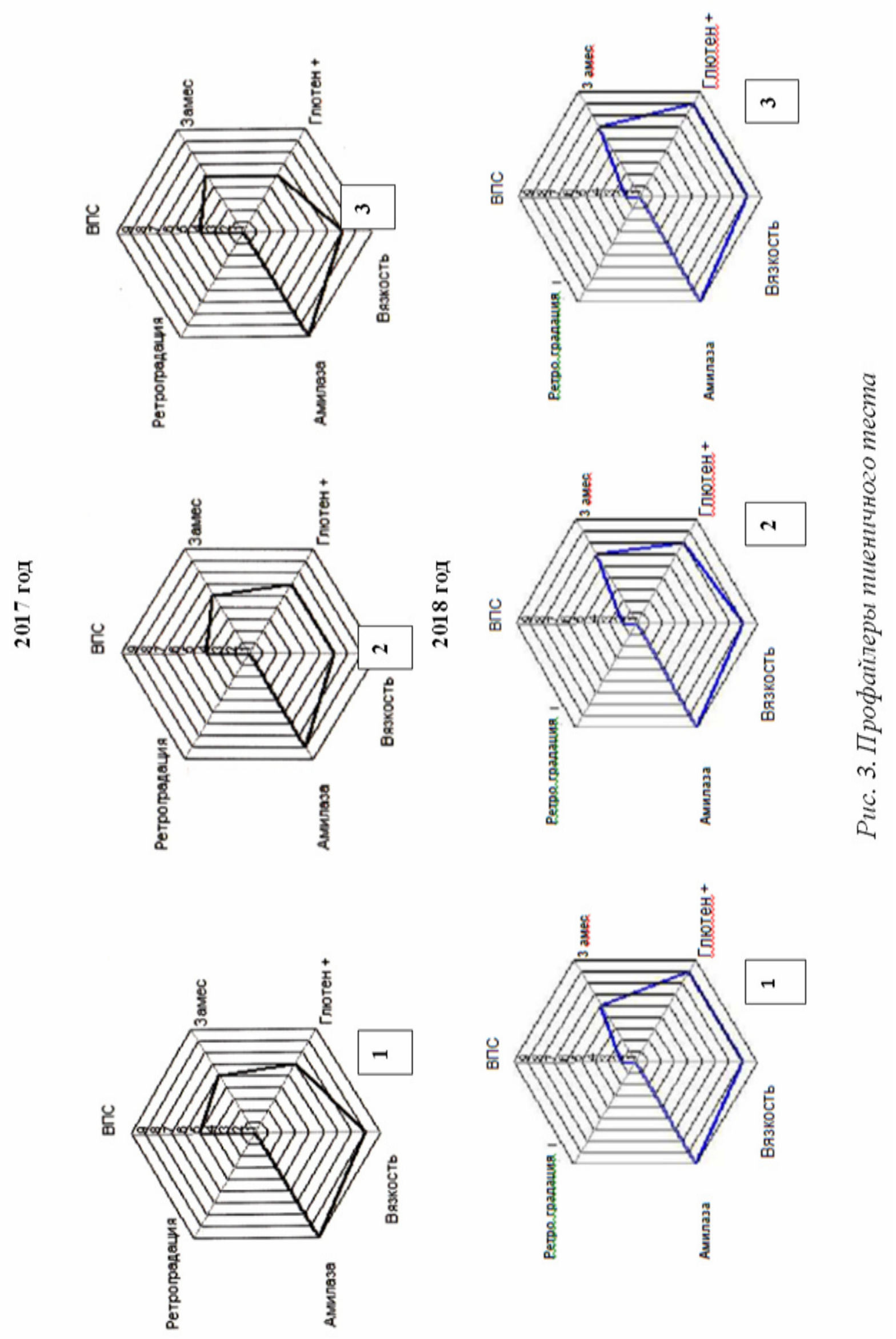
Содержание аминокислот в пшеничной муке по вариантам опыта, 2018 д., \%

\begin{tabular}{|l|c|c|c|}
\hline \multirow{2}{*}{ Аминокислота } & \multicolumn{3}{|c|}{ Вариант опыта } \\
\cline { 2 - 4 } & $\mathrm{NH}_{4} \mathrm{NO}_{3}$ (контроль) & $\mathrm{NH}_{4} \mathrm{NO}_{3}+\mathrm{S} 5 \%$ & $\mathrm{NH}_{4} \mathrm{NO}_{3}+\mathrm{S} 10 \%$ \\
\hline Аргинин & $0,36 \pm 0,15$ & $0,38 \pm 0,15$ & $0,41 \pm 0,16$ \\
\hline Лизин & $0,16 \pm 0,05$ & $0,17 \pm 0,06$ & $0,16 \pm 0,06$ \\
\hline Тирозин & $0,31 \pm 0,09$ & $0,32 \pm 0,10$ & $0,33 \pm 0,10$ \\
\hline Фенилаланин & $1,52 \pm 0,46$ & $0,81 \pm 0,24$ & $1,01 \pm 0,30$ \\
\hline Гистидин & 0,01 & 0,01 & 0,01 \\
\hline Лейцин + Изолейцин & $1,77 \pm 0,46$ & $1,85 \pm 0,48$ & $1,86 \pm 0,48$ \\
\hline Метионин, & 0,01 & 0,01 & 0,01 \\
\hline Валин & $0,46 \pm 0,18$ & $0,48 \pm 0,19$ & $0,47 \pm 0,19$ \\
\hline Пролин & $2,08 \pm 0,54$ & $2,18 \pm 0,57$ & $2,15 \pm 0,56$ \\
\hline Треонин & $0,32 \pm 0,13$ & $0,33 \pm 0,13$ & $0,38 \pm 0,15$ \\
\hline Серин & $0,39 \pm 0,10$ & $0,41 \pm 0,11$ & $0,40 \pm 0,10$ \\
\hline Аланин, & $0,56 \pm 0,15$ & $0,59 \pm 0,15$ & $0,58 \pm 0,15$ \\
\hline Глицин & $0,43 \pm 0,15$ & $0,45 \pm 0,15$ & $0,44 \pm 0,15$ \\
\hline Триптофран & $0,09 \pm 0,04$ & $0,10 \pm 0,04$ & $0,09 \pm 0,04$ \\
\hline
\end{tabular}

Профайлеры пшеничного теста представлены на рисунке 3.

Индекс ВПС в вариантах опыта 2018 г. ниже на две-три единицы, т. к. содержание сырой клейковины в муке из зерна 2018 г. ниже на 1,3-2,0 \% по сравнению с вариантами опыта 2017 г. (табл. 1).

Серосодержащие удобрения влияют на белково-протеиназный комплекс пшеничной муки. Дисульфидная связь ковалентная связь между двумя атомами серы (-S-S-), входящими в состав серосодержащей аминокислоты цистеина. Для синтеза цистеина требуются две аминокислоты: серин - источник углеродного скелета; метионин - первичный источник атома S. B опытных вариантах содержание аминокислоты серин в пшеничной муке выше на 2,6-5,1 \% по сравнению с контролем (табл. 2).

Дисульфидные связи образуются в процессе посттрансляционной модификации белков и служат для поддержания третичной и четвертичной структур белка, в результате качество клейковины - хорошее (I группа) (табл. 1). Отличия по качеству клейковины между годами в контроле и варианте с внесением $5 \%$ серы значительно выше, по сравнению с разницей между вариантами. По-видимому, погод- ные условия лета 2017 года, когда в начале июля выпало рекордное для Ульяновской области количество осадков (163 мм), способствовали незначительному ослаблению клейковины.

При сравнении миксограмм (рис.1, 2) следует отметить, что в вариантах опыта 2018 г. в фразах С2 и С3 индекс вязкости повышается, изменяется консистенция теста при его нагреве до $90{ }^{\circ} \mathrm{C}$.

Фаза желатинизации крахмала указывает на высокую консистенцию теста при выпечке, и низкую автолитическую активность образцов на опытных вариантах (табл. 3).

Высокий индекс глютен + означает значительную устойчивость протеиновой структуры клейковины.

Чем выше показатель индекса вязкости, тем выше консистенция теста при выпечке. В урожае 2018 года отличия по вариантам не обнаружено. Индекс замешивания зависит от поведения теста при замешивании, в особенности от стабильности. Чем выше индекс, тем устойчивее будет тесто при замесе. Индексы большинства образцов указывают на стабильные показатели силы теста в интервале от 5 до 6 баллов, в том числе и по контрольному образцу.

Таблица 3

Реологические показатели муки озимой мягкой пшеницы протокол Chopin+

\begin{tabular}{|l|c|c|c|c|c|c|c|c|c|c|}
\hline $\begin{array}{c}\text { Вариант } \\
\text { опыта }\end{array}$ & \multicolumn{2}{|c|}{ ВПС } & \multicolumn{2}{c|}{ Замес } & \multicolumn{2}{c|}{ Глютен+ } & \multicolumn{2}{c|}{ Вязкость } & \multicolumn{2}{c|}{ Амилаза } \\
\hline $\begin{array}{l}\mathrm{NH}_{4} \mathrm{NO}_{3} \\
(\text { контроль) }\end{array}$ & 4 & 1 & 5 & 5 & 6 & 8 & 8 & 8 & 9 & 9 \\
\hline $\begin{array}{l}\mathrm{NH}_{4} \mathrm{NO}_{3}+ \\
\mathrm{S} \mathrm{5}_{\%}\end{array}$ & 3 & 1 & 5 & 6 & 6 & 7 & 6 & 8 & 8 & 9 \\
\hline $\begin{array}{l}\mathrm{NH}_{4} \mathrm{NO}_{3}+ \\
\mathrm{S} 10 \%\end{array}$ & 3 & 1 & 5 & 6 & 5 & 8 & 7 & 8 & 9 & 9 \\
\hline
\end{tabular}


Показатели качества готовых изделий

\begin{tabular}{|c|c|c|c|c|c|c|}
\hline \multirow{2}{*}{ Вариант } & \multicolumn{2}{|c|}{ Пористость } & \multicolumn{2}{c|}{ Удельный объем } & \multicolumn{2}{c|}{$\begin{array}{c}\text { Формоустойчивость } \\
\text { подового хлеба }\end{array}$} \\
\cline { 2 - 7 } & 2017 г. & 2018 г. & 2017 г. & 2018 г. & 2017 г. & 2018 г. \\
\hline $\mathrm{NH}_{4} \mathrm{NO}_{3}$ (контроль) & 68,4 & 73,0 & 2,28 & 2,98 & 0,6 & 0,78 \\
\hline $\mathrm{NH}_{4} \mathrm{NO}_{3}+\mathrm{S}$ (5 \%) & 66,3 & 73,0 & 1,95 & 2,98 & 0,6 & 0,63 \\
\hline $\mathrm{NH}_{4} \mathrm{NO}_{3}+\mathrm{S}(10 \%)$ & 68,1 & 74,0 & 2,16 & 3,13 & 0,44 & 0,7 \\
\hline
\end{tabular}

Результаты пробной выпечки показаны в таблице 4.

При сравнении результатов, полученных с прибора миксолаб и пробной лабораторной выпечки (табл. 4), видно, что использование серосодержащих удобрений при ранневесенней подкормке озимой пшеницы неоднозначно влияет на качество готовых изделий по годам. По-видимому, избыточное количество осадков в июле 2017 года внесло свою корректировку в вышеназванные показатели.

\section{Заключение}

Ранневесенняя подкормка озимой пшеницы аммиачной селитрой с добавлением 10 кг д. в сульфата аммония позволяет получить зерно хлебопекарных кондиций. Высокие показатели пористости, удельного объема хлеба и формоусточивости указывают на зависимость этих параметров от хлебопекарных показателей исходного сырья. Выход хлеба при этом увеличивается на 3,5-4,2 \%.

\section{Лuтература}

1. Влияние массовой доли амарантовой муки на количественную выраженность показателей реологических свойств пшеничного теста / Т. Б. Кулеватова, Л. В. Андреева, С. Г. Лихацкая [и др.] // Агро XXI. - 2013. - № 1-3. - С. 47-48.

2. Информативность нетрадиционных критериев технологических свойств теста на основе зерна озимой мягкой пшеницы / Т. Б. Кулеватова, Л. Н. Злобина, С. В. Лящева [и др.] // Хлебопродукты. - 2018. - № 9. - С. 46-50.

3. К методике тестирования качества озимой пшеницы / Т. Б. Кулеватова, Л. В. Андреева, А. И. Прянишников [и др.] // Достижения науки и техники АПК. - 2016. - Т. 30. - № 6. - С. 25-28.

4. Качество зерна - источник здоровья нации / А. И. Прянишников, Л. В. Андреева, Т. Б. Кулеватова [и др.] // Достижения науки и техники АПК. - 2010. - № 11. - С. 16-17.

5. Костин, В. И. Элементы минерального питания и росторегуляторы в онтогенезе сельскохозяйственных растений: монография / В. И. Костин, В. А. Исайчев, О. В. Костин. - Москва: Колос, 2006. $-290 \mathrm{c}$.

6. Влияние поражения зерна озимой пшеницы клопом-черепашкой (Eurygaster Integriceps Put) на показатели реологических свойств теста /Т.Б. Кулеватова, Л. В. Андреева, Г.В.Пискунова [и др.] // Агро XXI. - 2013. - № 4-6. - С. 27-28.

7. Кулеватова, Т. Б. Разграничивающая способность показателей вискографра и их согласованность характеристиками качества зерна озимой ржи / Т.Б. Кулеватова, В. М. Бебякин, С. В. Осипова // Аграрный вестник Юго-Востока. - 2009. - № 3 (3). - С. 28-30.

8. Мударисов, Ф. А. Оценка влияния агротехнических приемов возделывания озимой пшеницы на качество муки на основании реологического профиля теста / Ф. А. Мударисов, М. К. Садыгова, В. И. Костин // Вестник Мичуринского ГАУ. - 2018. -№ 2. - С. 50-56.

9. О качестве зерна озимой пшеницы / Т. Б. Кулеватова, Л. В. Андреева, Д. В. Кайргалиев [и др.] // Известия Нижневолжского агроуниверситетского комплекса: Наука и высшее профессиональное образование. - 2014. - № 4 (36). - С. 80-84.

10. Пучкова, Л.И.Лабораторный практикум по технологии хлебопекарского производства / Л. И. Пучкова. - Санкт-Петербург: ГИОРД, 2004. - 264 с.

11. Сулейманов, И. Р. Агрохимическая оценка эффеективности применения серосодержащих удобрений на серой лесной почве Предволжья Республики Татарстан: автореферат диссертации на соискание ученой степени кандидата сельскохозяйственных наук / И. Р. Сулейманов. - Казань, 2011. -20 c.

12. Танделов, Ю. П. Роль серосодержащих удобрений в оптимизации минерального питания серой лесной и дерновоподзолистой почвах Красноярской подтайги / Ю. П. Танделов, М. С. Патрина // Вестник КрасГАУ. - 2011. - № 11 (62). - С. 66-70.

13. Характеристика пахотных почв Ульяновской области по содержанию микроэлементов и эфффективность применения микроэлементсодержащих препаратов / Е. А. Черкасов, В. А. Исайчев, Б. К. Саматов [и др.] // Вестник Ульяновской государственной сельскохозяйственной академии. - 2012. - № 4 (20). - С. 30-34.

14. Черкасов, О. В. Лабораторный практикум по контролю сырья, полуфабрикатов и готовой продукции хлебопекарного производства / О. В. Черкасов. - Рязань: Рязанский ГАТУ, 2010. - 103 с. 
15. Черных, И. В. Совершенствование контроля качества муки с использованием современных информационно-измерительных систем / И.В.Черных, А. В. Лебедев // Хлебопродукты. 2012. - № 6. - C. 41-43.

16. Самотоенко, А. С. Влияние микроэлементов и серы на урожайность и качество озимой пшеницы в условиях типичного и обыкновенного чернозёмов Воронежской области: автореферат диссертации кандидата сельскохозяйственных наук / А. С. Самотоенко. - Москва, 2001. - 26 с.

17. Chandra, N. Role of sulfur nutrition in plant and seed metabolism of glycine max L. / N. Chandra, N. Pandey // Journal of Plant Nutrition. - 2016. - № 39 (8). - P. 1103-1111. doi:10.1080/01904167.2016.1143495

18. Hussain, Z. Effects of foliar applied sulfur and commercial growth regulators in wheat. / Z. Hussain, M. H. Leitch // Journal of Plant Nutrition. - 2008. - № 31 (10). - P. 1699-1710. doi:10.1080/ 01904160802324621

19. Spatial patterns of gluten protein and polymer distribution in wheat grain / J. He, S. Penson, S. J. Powers [et al.] // Journal of Agricultural and Food Chemistry. - 2013. - № 61(26). - P. 6207-6215. doi:10.1021/jf401623d

UDC 664.64.016.8

DOI: $10.36461 / N P .2019 .52 .3 .010$

\section{INFLUENCE OF EARLY-SPRING FERTILIZING WITH SULPHUR-CONTAINING MINERAL FERTILIZERS ON THE QUALITY OF WINTER WHEAT GRAIN FLOUR}

\section{F. A. Mudarisov ${ }^{1}$, Candidate of Agricultural sciences, assistant-professor;}

M. K. Sadygova ${ }^{2}$, Doctor of Technical sciences, professor; E. Sh. Minacheva ${ }^{2}$, post-graduate student;

A. A. Galiullin ${ }^{3}$, Candidate of Agricultural sciences, assistant-professor

${ }^{1}$ Federal State Budgetary Educational Institution of Higher Education « Ulyanovsk State Agrarian University n. a. P. A. Stolypin», Russia, t. 8(8422) 55-95-47, e-mail: fail_76@mail.ru;

${ }^{2}$ Federal State Budgetary Educational Institution of Higher Education «Saratov State Agrarian

University n. a. N. I. Vavilov», Russia, t. 8 (8452) 23-32-92, e-mail: sadigova.madina@yandex.ru

${ }_{3}^{3}$ Federal State Budgetary Educational Institution of Higher Education «Penza State Agrarian University», Russia, t. 8(8412) 628-151

Wheat flour obtained from winter soft wheat grain of the Saratovskaya 17 variety, grown under the conditions of leached, medium-power, low-humus, medium loamy black soil of the Middle Volga region of the Russian Federation (Ulyanovsk Region) in 2017-2018 was studied in the work. According to leading experts in the field of plant nutrition, the presence of sufficient sulphur in cultivated plants is the main factor in obtaining high-quality protein compounds. The effect of early spring fertilizing with ammonium nitrate with the addition of ammonium sulfate in the amount of 5 and $10 \%$ was studied. The crude gluten content in 2018 grain flour was lower by 4.5-7.0 \% compared with the 2017 test variants; therefore, the water-absorbing capacity (WAC) in the 2018 test variants was two to three units lower. The use of sulfur-containing fertilizers in the early spring feeding of winter wheat affected the quality of finished products. When applying sulphur-containing fertilizers in the amount of $10 \%$, high porosity, specific volume of bread, and form stability were obtained, which showed the dependence of these indicators on gluten, viscosity, and amylase indices.

Key words: mixolab, test profile, profiler index, gluten index, sulphur fertilizers.

\section{References:}

1. The influence of the mass fraction of amaranth flour on the quantitative severity of the rheological properties of wheat dough / T. B. Kulevatova, L. V. Andreeva, S. G. Likhatskaya [et al.] // Agro XXI. 2013. - No. 1-3. - p. 47-48.

2. Informativeness of non-traditional criteria of technological properties of the test based on grain of winter soft wheat / T. B. Kulevatova, L. N. Zlobina, S. V. Lyashcheva [et al.] // Khleboproducty. - 2018. No. 9. - p. 46-50.

3. On the methodology for testing the quality of winter wheat / T. B. Kulevatova, L. V. Andreeva, A. I. Pryanishnikov [et al.] // Achievements of science and technology of the agro-industrial complex. 2016. - V. 30. - No. 6. - p. 25-28.

4. Grain quality - the source of the health of the nation / A. I. Pryanishnikov, L. V. Andreeva, T. B. Kulevatova [et al.] // Achievements of science and technology of the agro-industrial complex. 2010. - No. 11. - p. 16-17.

5. Kostin, V. I. Elements of mineral nutrition and growth regulators in the ontogenesis of agricultural plants: monograph / V. I. Kostin, V. A. Isaichev, O. V. Kostin. - Moscow: Kolos, 2006.-- 290 p. 
6. The effect of winter wheat grain damage by the corn-bug (Eurygaster Integriceps Put) on the rheological properties of the test / T. B. Kulevatova, L. V. Andreeva, G. V. Piskunova [et al.] // Agro XXI. - 2013. - No. 4-6. - p. 27-28.

7. Kulevatova, T. B. The differentiating ability of viscograph indicators and their consistency with winter rye grain quality characteristics / T. B. Kulevatova, V. M. Bebyakin, S. V. Osipova // Agrarian Bulletin of the South-East. - 2009. - No. 3 (3). - p. 28-30.

8. Mudarisov, F. A. Evaluation of the influence of agrotechnical methods of winter wheat cultivation on the quality of flour based on the rheological profile of the test / F. A. Mudarisov, M. K. Sadigova, V. I. Kostin // Bulletin of the Michurinsky SAU. - 2018. -№ 2. - p. 50-56.

9. On the quality of grain of winter wheat / T. B. Kulevatova, L. V. Andreeva, D. V. Kayrgaliev [et al.] // Izvestiya Nizhnevolzhskogo agrouniversitetskogo kompleksa: Nauka i vysshee professional'noe obrazovanie. - 2014. - No. 4 (36). - p. 80-84.

10. Puchkova, L. I. Laboratory workshop on the technology of bakery production / L. I. Puchkova. St. Petersburg: GIORD, 2004.-- 264 p.

11. Suleymanov, I. R. Agrochemical evaluation of the effectiveness of the use of sulphur-containing fertilizers on gray forest soil of the Volga of the Republic of Tatarstan: an abstract of a dissertation for the degree of candidate of agricultural sciences / I. R. Suleymanov. - Kazan, 2011.-- 20 p.

12. Tandelov, Yu. P. The role of sulphur-containing fertilizers in optimizing the mineral nutrition of gray forest and sod-podzolic soils of the Krasnoyarsk subtaiga / Yu. P. Tandelov, M. S. Patrina // Bulletin of KrasSAU. - 2011. - No. 11 (62). - p. 66-70.

13. The characteristic of arable soils of the Ulyanovsk region on the content of micro-elements and the effectiveness of the use of micro-elements / E. A. Cherkasov, V. A. Isaichev, B. K. Samatov [et al.] // Bulletin of the Ulyanovsk State Agricultural Academy. - 2012. - No. 4 (20). - p. 30-34.

14. Cherkasov, O. V. Laboratory workshop for the control of raw materials, semi-finished products and finished products of bakery production / O. V. Cherkasov. - Ryazan: Ryazan SATU, 2010.-- 103 p.

15. Chernykh, I. V. Improving the quality control of flour using modern information-measuring systems / I. V. Chernykh, A. V. Lebedev // Kheboproducty. - 2012. - No. 6. - p. 41-43.

16. Samotoenko, A. S. The influence of microelements and sulfur on the productivity and quality of winter wheat in the conditions of a typical and ordinary chernozem of the Voronezh region: abstract of the dissertation of the candidate of agricultural sciences / A. S. Samotoenko. - Moscow, 2001.-- 26 p.

17. Chandra, N. Role of sulfur nutrition in plant and seed metabolism of glycine max L. / N. Chandra, N. Pandey // Journal of Plant Nutrition. - 2016. - № 39 (8). - P. 1103-1111. doi:10.1080/ 01904167.2016.1143495

18. Hussain, Z. Effects of foliar applied sulfur and commercial growth regulators in wheat. / Z. Hussain, M. H. Leitch // Journal of Plant Nutrition. - 2008. - № 31 (10). - P. 1699-1710. doi:10.1080/ 01904160802324621

19. Spatial patterns of gluten protein and polymer distribution in wheat grain / J. He, S. Penson, S. J. Powers [et al.] // Journal of Agricultural and Food Chemistry. - 2013. - № 61(26). - P. 6207-6215. doi:10.1021/jf401623d 